\title{
PENERAPAN MODEL PEMBELAJARAN KOOPERATIF TIPE COOPERATIVE INTEGRATED READING AND COMPOSITION DISELIPKAN TEKNIK ICE BREAKING UNTUK MENINGKATKAN AKTIVITAS BELAJAR SISWA KELAS III SD DWIJENDRA DENPASAR
}

\author{
Ni Putu Anita Adriyanti \\ Program Studi Pendidikan Guru Sekolah Dasar, Fakultas Keguruan dan Ilmu Pendidikan, Universitas \\ Dwijendra \\ anitaadrianti98@gmail.com \\ Ni Luh Gede Karang Widiastuti \\ Program Studi Pendidikan Guru Sekolah Dasar, Fakultas Keguruan dan Ilmu Pendidikan, Universitas \\ Dwijendra \\ karangwidhi@gmail.com
}

\section{Putu Edy Purnawijaya}

Program Studi Pendidikan Guru Sekolah Dasar, Fakultas Keguruan dan Ilmu Pendidikan, Universitas Dwijendra coqajoes04@yahoo.co.id

\begin{abstract}
Abstrak
Penelitian ini bertujuan untuk mengetahui penerapan model pembelajaran kooperatif tipe Cooperative Integrated Reading and Composition Diselipkan Teknik Ice Breaking untuk meningkatkan aktivitas belajar siswa kelas III SD Dwijendra Denpasar. Jenis penelitian ini adalah Penelitian Tindakan Kelas (PTK) yang terdiri dari 2 siklus. Setiap siklus terdiri dari observasi, perencanaan, pelaksanaan/tindakan dan refleksi. Subjek penelitian ini adalah siswa kelas III SD Dwijendra Denpasar dengan jumlah siswa 24 orang yang terdiri dari 14 siswa perempuan dan 10 siswa laki-laki. Data mengenai aktivitas belajar diperoleh menggunakan metode observasi dengan instrumen yang berbentuk lembar observasi. Teknik analisis yang digunakan dalam penelitian ini adalah teknik analisis deskriptif kuantitatif. Hal ini dapat dilihat dari persentase rata-rata aktivitas belajar yang diperoleh yaitu pada refleksi awal (prasiklus) rata-rata aktivitas belajar hanya mencapai 60,07\% yang berada pada kategori "kurang aktif". Berdasarkan hasil penelitian dari siklus I sampai pada siklus ke II, aktivitas belajar berupa persentase rata-rata pada siklus I yaitu 68,24\% yang berada pada kategori "cukup aktif". Setelah diadakan perbaikan tindakan pada siklus II, rata-rata aktivitas belajar siswa semakin meningkat menjadi $80,14 \%$ yang berada pada kategori "aktif" sehingga terjadinya peningkatan persentase rata-rata aktivitas belajar siswa dari siklus I ke siklus II sebesar 11,90\%. Berdasarkan hasil analisis yang telah dilaksanakan, dapat disimpulkan bahwa model pembelajaran kooperatif tipe Cooperative Integrated Reading and Composition Diselipkan Teknik Ice Breaking dapat meningkatkan aktivitas belajar siswa kelas III SD Dwijendra Denpasar.
\end{abstract}

Kata kunci : Model Pembelajaran kooperatif, Cooperative Integrated Reading and Composition, Teknik Ice Breaking, Aktivitas Belajar Siswa 


\begin{abstract}
This study aims to determine the application of the cooperative learning model type Cooperative Integrated Reading and Composition. Ice Breaking Technique is inserted to increase the learning activities of the third grade students of SD Dwijendra Denpasar. This type of research is Classroom Action Research (CAR) which consists of 2 cycles. Each cycle consists of observation, planning, action / action and reflection. The subjects of this study were students of class III SD Dwijendra Denpasar with 24 students consisting of 14 female students and 10 male students. Data regarding learning activities were obtained using the observation method with an instrument in the form of an observation sheet. The analysis technique used in this research is quantitative descriptive analysis technique. This can be seen from the average percentage of learning activities obtained, namely in the early reflection (pre-cycle) the average learning activity only reached $60.07 \%$ which was in the "less active" category. Based on the results of research from cycle I to cycle II, learning activities in the form of an average percentage in the first cycle were $68.24 \%$ which were in the "moderately active" category. After improving the action in cycle II, the average student learning activity increased to $80.14 \%$ which is in the "active" category so that an increase in the average percentage of student learning activities from cycle I to cycle II is $11.90 \%$. Based on the results of the analysis that has been carried out, it can be concluded that the cooperative learning model type Cooperative Integrated Reading and Composition with Ice Breaking Technique inserted can increase the learning activities of third grade students of SD Dwijendra Denpasar.
\end{abstract}

Keywords: Cooperative Learning Model Type Cooperative Integrated Reading and Composition, Ice Breaking Technique, Student Learning Activities 


\section{PENDAHULUAN}

\section{Pendidikan merupakan suatu} proses reorganisasi dan rekonstruksi (penyusunan kembali) pengalaman yang bertujuan menambah efisiensi individu dalam interaksinya dengan lingkungan (Trianto, 2011:44). Hal ini dikarenakan pendidikan merupakan sarana paling efektif untuk meningkatkan kualitas hidup dan kesejahteraan masyarakat (Santika, 2019). Untuk itu dalam suatu proses pembelajaran, peserta didik harus berperan aktif dalam mengembangkan potensi dirinya. Penerapan pembelajaran saat ini menggunakan Kurikulum 2013 revisi, dimana kurikulum ini merupakan kurikulum yang terus menerus diuji cobakan dan selalu mengalami perubahan. Kurikulum 2013 untuk sekolah dasar didesain dengan menggunakan pembelajaran tematik terpadu. Pembelajaran tematik terpadu di sekolah dasar menggunakan tema sebagai pemersatu kegiatan pembelajaran yang memadukan beberapa mata pelajaran sekaligus dalam satu kali pertemuan, untuk memberikan pengalaman yang bermakna bagi peserta didik. Hal ini bertujuan agar siswa dapat memusatkan perhatian pada satu tema atau topik tertentu, mengembangkan berbagai kompetensi muatan pelajaran dalam tema yang sama, memahami materi pelajaran lebih mendalam dan berkesan. Sehingga aspek perilaku tersentuh dan siswa lebih aktif dalam proses pembelajaran. Namun, kenyataan dilapangan dalam proses pembelajaran masih ditemukan permasalahan-permasalahan yang terjadi. Permasalahan- permasalahan tersebut antara lain pembelajaran belum maksimal karena, guru hanya menggunakan metode ceramah, kurangnya konsentrasi siswa saat guru mengajar, serta materi pelajaran tidak tersampaikan secara terperinci. Dalam proses pembelajaran aktivitas siswa hanya patuh terhadap apa yang disampaikan guru, guru cenderung hanya memberikan tugas dan mencatat saja. Di dalam Kurikulum 2013 ini lebih menekankan pada peran aktif siswa dalam proses pembelajaran dan pengembangan diri yang dilaksanakan. Dengan kata lain, bahwa dalam belajar sangat diperlukan aktivitas. Tanpa aktivitas, proses belajar tidak akan berlangsung dengan baik. Berdasarkan hasil observasi dan wawancara dengan guru kelas III di Sekolah Dasar Dwijendra Denpasar pada tanggal 27 Nopember 2019, menunjukkan bahwa pembelajaran tema 4 sub tema 3 , secara umum masih bersifat konvensional dimana guru lebih mendominasi dengan menggunakan metode ceramah, tanyajawab maupun pemberian tugas di dalam kelas, tidak ada teknik pembelajaran yang menarik perhatian siswa. Dalam menyampaikan materi guru masih menggunakan metode ceramah tanpa berbantuan teknik apapun. Kebiasaan guru yang ingin mendominasi kegiatan pembelajaran di kelas dapat mengakibatkan siswa memusatkan perhatian pada hal lain seperti bercanda bersama teman sebangkunya dan diikuti oleh siswa yang lain. Siswa cenderung tidak memahami apa yang sedang dipelajari, kurangnya konsentrasi siswa, timbulnya rasa malu dalam diri siswa untuk bertanya. Kondisi proses pembelajaran ini berakibat pada rendahnya aktivitas belajar siswa. Hal ini ditunjukkan berdasarkan dari hasil pengamatan 24 siswa terdapat 17 siswa atau $40 \%$ aktivitas cukup tinggi, 5 siswa atau $36 \%$ aktivitas kurang, dan 2 siswa atau $24 \%$ aktivitas sangat rendah. Adapun cara yang ditempuh guru untuk mengatasi permasalahan tersebut yaitu dengan menggunakan model pembelajaran kooperatif tipe CIRC (Cooperative Integrated Reading and Composition). Model pembelajaran kooperatif tipe cooperative integrated reading and composition pertama kali dikembangkan oleh oleh Steven, Slavin dan kolega pada akhir tahun 1980. Model pembelajaran tipe cooperative integrated reading and composition tidak hanya digunakan di kelas-kelas tinggi sekolah dasar saja, tetapi juga di kelas III. CIRC atau pembelajaran terpadu merupakan pembelajaran kooperatif dimana setiap siswa bertanggung jawab terhadap tugas kelompok. Model ini dikembangkan untuk meningkatkan kemampuan peserta didik dalam membaca dan menerima umpan balik dari kegiatan membaca yang telah dilakukan. Ini akan membuat teks bagus dan mudah dibaca (Swarniti, 2021). Kelebihan model pembelajaran cooperative integrated reading and composition (CIRC) menurut Saifulloh (Huda, 2013:221), kelebihannya 
antara lain: (1) Pengalaman dan kegiatan belajar siswa selalu relevan dengan tingkat perkembangan siswa. (2) Kegiatan pembelajaran sesuai dengan kebutuhan siswa. (3) Pembelajaran lebih bermakna bagi siswa. (4) Menumbuh-kembangkan keterampilan berfikir siswa. (5) Menyajikan kegiatan yang bersifat pragmatis (bermanfaat). (6) Menumbuh-kembangkan interaksi sosial siswa, seperti kerja sama, toleransi, komunikasi, dan menghargai gagasan orang lain. (7) Membangkitkan semangat belajar siswa dan guru. Model pembelajaran kooperatif tipe cooperative integrated reading and composition dalam implementasinya dapat dipadukan dengan teknik pembelajaran. Menurut Sanjaya (2010) Teknik pembelajaran dapat diartikan sebagai cara yang dilakukan seseorang dalam mengimplementasikan suatu metode secara spesifik. Salah satu teknik pembelajaran yang cocok digunakan dalam model pembelajaran kooperatif tipe cooperative integrated reading and composition yaitu teknik ice breaking. Teknik ice breaking adalah teknik pembelajaran yang menggunakan suatu

\section{METODE}

Jenis penelitian ini adalah penelitian tindakan berbasis kelas (classroom-based action research) sebagai upaya perbaikan pembelajaran di sekolah pada umumnya dan di dalam kelas pada

$$
\begin{aligned}
& \text { Siklus I } \\
& 1=\text { Perencanaan } 1 \\
& 2=\text { Tindakan } 1 \\
& 3=\text { Observasi } 1 \\
& 4=\text { Refleksi } 1
\end{aligned}
$$

Siklus II

1 = Revisi rencana 1 dan perencanaan II

2 = Tindakan II

3 = Observasi II

4 = Refleksi II

Subjek penelitian ini adalah siswa kelas III tahun pelajaran 2019/2020. Siswa kelas III SD Dwijendra Denpasar ini berjumlah 24 siswa yang terdiri dari 14 perempuan dan 10 siswa laki-laki. Metode pengumpulan data dilakukan melalui observasi dan dokumentasi dengan instrumen penilaiannya menggunakan

$$
\mathrm{M}^{\Sigma}
$$

Keterangan:

$\mathrm{M}=$ Skor rata-rata aktivitas siswa permainan yang berfungsi untuk mengubah suasana kebekuan dalam suatu kelompok. Teknik pembelajaran ice breaking dapat menumbuhkan semangat siswa, membangkitkan gairah belajar dan dapat membangun suasana belajar yang penuh kegembiraan. Kelebihan menggunakan teknik ice breaking yaitu (1) Membuat waktu panjang terasa cepat; (2) Membawa dampak menyenangkan dalam pembelajaran; (3) Dapat digunakan secara sepontan atau terkonsep; (4) Membuat suasana kompak dan menyatu. Berdasarkan uraian tersebut peneliti tertarik untuk melakukan penelitian yang berjudul "Penerapan Model Pembelajaran Kooperatif Tipe Cooperative Integrated Reading and Composition Diselipkan Teknik Ice Breaking untuk Meningkatkan Aktivitas Belajar Siswa Kelas III SD Dwijendra Denpasar. Tujuan penelitian ini adalah untuk mengetahui penerapan model pembelajaran kooperatif tipe cooperative integrated reading and composition diselipkan teknik ice breaking dalam meningkatkan aktivitas belajar siswa kelas III SD Dwijendra Denpasar.

khususnya. Model penelitian ini menggunakan tindakan kelas Arikunto (2014:16) secara garis besar terdapat empat tahapan model penelitian tindakan, yaitu :

lembar observasi. Teknik analisis data yang digunakan dalam penelitian ini adalah teknik analisis deskriptif kuantitatif. Analisis data pada siswa mengenai aktivitas belajar dilakukan melalui observasi, yang datanya kemudian dianalisis dengan cara berikut: 
$\sum \mathrm{X}=$ Jumlah skor aktivitas

$N \quad=$ Banyaknya siswa, (Dalam Agung, 2014)

Menentukan persentase aktivitasnya digunakan rumus sebagai berikut.

Keterangan:

$\mathrm{P} \quad=$ Persentase aktivitas belajar

$\mathrm{M} \quad=$ Rata-rata

SMI = Skor Maksimal Ideal

(dalam Agung, 2014)

Persentase rata-rata aktivitas belajar siswa setiap siklus

Menentukan persentase rata-rata aktivitas belajar siswa setiap siklus dengan rumus:

Persentase rata-rata aktivitas belajar siswa setiap siklus:

Untuk mengetahui tingkat ketercapaian aktivitas belajar digunakan konversi PAP Skala lima tingkatan aktivitas belajar dapat menggunakan pedoman konversi PAP skala lima dilihat pada tabel 1.

Kemudian dimodifikasi menjadi bentuk yang sederhana. Pedoman konversi PAP skala lima tentang kriteria penilaian aktivitas belajar siswa dapat dilihat pada tabel berikut:

Tabel 1. Pedoman Konversi PAP Skala Lima Tentang Aktivitas Belajar

\begin{tabular}{|c|c|c|}
\hline No & Persentase & Kriteria Aktivitas Belajar \\
\hline 1 & $90 \%-100 \%$ & Sangat Aktif \\
\hline 2 & $80 \%-89 \%$ & Aktif \\
\hline 3 & $65 \%-79 \%$ & Cukup Aktif \\
\hline 4 & $55 \%-64 \%$ & Kurang Aktif \\
\hline 5 & $0 \%-54 \%$ & Sangat Kurang Aktif \\
\hline
\end{tabular}

(dalam Agung, 2014)

\section{HASIL DAN PEMBAHASAN}

Penelitian tindakan kelas ini dilaksanakan pada semester genap pada bulan April 2020 dengan mengambil Tema 4 Sub tema 3 pembelajaran 1 sampai pembelajaran 6. Penelitian ini dilaksanakan di SD Dwijendra Denpasar tahun ajaran 2019/2020 dengan subjek penelitian adalah kelas III, sebanyak 24 orang siswa yang terdiri dari 10 orang siswa laki-laki dan 14 orang siswa perempuan. Penelitian ini dilaksanakan dalam dua siklus, setiap siklus dilaksanakan dalam tiga kali pertemuan yaitu tiga kali pertemuan untuk pembelajaran dan observasi untuk mengukur aktivitas belajar siswa siklus I dan siklus II. Setiap pertemuan dialokasikan waktu 6 jam pelajaran $(6$ x 35 menit)

Data yang dikumpulkan dalam penelitian ini, yaitu data tentang peningkatan aktivitas belajar siswa pada Tema 4 Sub tema 3 pembelajaran 1 sampai pembelajaran 6 dalam pembelajaran tematik. Data peningkatan aktivitas belajar pada Tema 4 Sub tema 3 pembelajaran 1 sampai pembelajaran 6. Siswa dikumpulkan pada pertemuan 1 sampai pertemuan ke 3 pada siklus I, dan pertemuan ke 4 sampai pertemuan ke 6 pada siklus II. Data yang telah dikumpulkan, dianalisis dengan metode analisis deskriptif kuantitatif. Analisis data mengenai peningkatan aktivitas belajar siswa pada Tema 4 subtema 3, dapat dijelaskan sebagai berikut:

\subsection{Hasil Refleksi Awal}


Penelitian diawali dengan kegiatan observasi peneliti pada siswa kelas III Dwijendra Denpasar pada proses pembelajaran tema 4 subtema 3 observasi dilakukan untuk mengetahui aktivitas belajar siswa pada tema sebelum tindakan. Hasil observasi ini menjadi acuan perencanaan tindakan. Berikut tabel kegiatan observasi sebelum pelaksanaan tindakan:

Tabel 2. Kegiatan Pengamatan Kondisi Awal atau Sebelum Tindakan

\begin{tabular}{|c|c|c|}
\hline No & Waktu & \multicolumn{1}{c|}{ Kegiatan } \\
\hline 1 & Senin, 27 Nopember 2019 & 1. $\begin{array}{l}\text { Melakukan observasi kegiatan pembelajaran teman 4 } \\
\text { subtema 3 di SD Dwijendra Denpasar }\end{array}$ \\
& 2. $\begin{array}{l}\text { Melakukan observasi dan wawancara terhadap guru } \\
\text { tentang aktivitas belajar siswa kelas III, sebanyak 6 } \\
\end{array}$ & $\begin{array}{l}\text { orang cukup aktif, sebanyak 16 orang kurang aktif } \\
\text { dan sebanyak 2 orang sangat kurang aktif. }\end{array}$ \\
& 3. $\begin{array}{l}\text { Menjelaskan tentang rencana penelitian } \\
\text { menggunakan model pembelajaran kooperatif tipe } \\
\text { cooperative integrated reading and composition } \\
\text { diselipkan teknik ice breaking pada guru kelas III SD } \\
\text { Dwijendra Denpasar. }\end{array}$ \\
\hline
\end{tabular}

Berdasarkan skema mengenai prosedur Penelitian Tindakan Kelas yang dilaksanakan dalam setiap siklus, tindakan menyarankan adanya kegiatan-kegiatan mengenai observasi, perencanaan, tindakan serta refleksi. Dalam hal ini peneliti pada siklus pertama juga akan menggunakan prosedur tersebut. Adapun tahapantahapannya adalah sebagai berikut : 
a) Perencanaan

Pada dasarnya perencanaan adalah tahap yang perlu dilalui untuk mengatasi rendahnya hasil belajar siswa, sekalipun penerapan model pembelajaran kooperatif tipe Cooperative Integrated Reading and Composition Diselipkan Teknik Ice Breaking agar siswa tersebut dapat meningkatkan aktivitas belajar siswa di dalam proses pembelajaran. Dalam tahap ini harus perlukan perencanaan yang matang sebelum tahap tindakan dilakukan.

b) Pelaksanaan

Pelaksanaan tindakan siklus I disesuaikan dengan RPP yang telah disusun pada tahap perencanaan. Pada siklus I terdiri dari tiga kali pertemuan untuk pembelajaran dan satu kali pertemuan untuk hasil akhir observasi untuk mengukur aktivitas belajar siswa pada siklus I. Pemberian tindakan dan observasi dilaksanakan pada tanggal 13, 14 dan 15 April 2020 dengan alokasi waktu setiap pertemuan 210 menit $(6 \mathrm{x}$ 35 menit) untuk mengukur aktivitas belajar siswa pada siklus I. Dalam penelitian ini, peneliti ini sebagai pemberi materi pembelajaran atau pengajar guru tematik, tindakan sebagai kolaborator dalam penelitian ini. Saat pembelajaran berlangsung, seorang peneliti melakukan kegiatan pembelajaran sesuai dengan RPP yang meliputi kegiatan pendahuluan, kegiatan inti, dan kegiatan penutup. Pembelajaran diawali dengan berdoa, setelah itu mengecek kehadiran siswa, kebersihan dan kerapian kelas, kesiapan buku tulis dan sumber belajar lainnya. Peneliti menerapkan model pembelajaran kooperatif tipe Cooperative Integrated Reading and Composition Diselipkan Teknik Ice Breaking dengan membagi siswa dalam kelompok kecil- kecil dalam kelas ada 24 siswa di bagi menjadi 6 kelompok, masing-masing kelompok memiliki anggota sebanyak 4 orang siswa. Cara pembagian kelompok dilakukan oleh peneliti berdasarkan posisi tempat duduk di kelas. Setelah semua anggota kelompok duduk menurut anggota kelompoknya masing - masing anggota kelompok memperoleh suatu gambaran bahan diskusi. Kemudian peneliti selanjutnya adalah memberikan pertanyaan - pertanyaan yang berkaitan dengan aktivitas siswa kepada siswa, peneliti mengamati beberapa siswa dalam mengerjakan tugas atau pertanyaan yang masih kebingungan namun dengan dibantu penjelasan oleh peneliti melalui ice breaking akhirnya mereka pun mengerti. Selanjutnya siswa memulai berdiskusi dengan kelompoknya masing-masing. Kemudian setiap kelompok diberikan kesempatan untuk mempresentasikan hasil diskusi bersama kelompoknya di depan kelas. Kelompok lain diberikan kesempatan untuk bertanya. Tujuan pemberian pertanyaan ini adalah agar siswa tersebut berpikir secara kritis dan tidak mengandalkan jawaban dari temannya.

c) Observasi

Pengamatan yaitu proses pelaksanaan pembelajaran yang dilakukan oleh pengamat.

Pengamatan dilakukan pada waktu yang sama dengan pelaksanaan tindakan, keduanya dilakukan bersamaan (Arikunto, 2010 : 139). Selama proses pembelajaran berlangsung peneliti berkolaborasi dengan teman sejawat untuk melakukan observasi aktivitas belajar siswa. Pada tahapan ini, dilakukan pengamatan dan pencatatan hal-hal yang diperlukan dan terjadi selama pelaksanaan tindakan berlangsung. Tujuan dilakukannya pengamatan adalah untuk mengetahui pengaruh yang ditimbulkan oleh perlakuan guru. Peneliti melakukan pengamatan aktivitas siswa dalam pembelajaran melalui model kooperatif tipe Cooperative Integrated Reading and Composition (CIRC) Diselipkan Teknik Ice Breaking. Pada tahap observasi dilakukan pengamatan mengenai kegiatan siswa saat proses pembelajaran berlangsung, terutama keaktifan dan cara kerja siswa dalam berkelompok, sehingga didapatkan data yang akurat tentang aktivitas belajar siswa sesuai dengan lembar observasi yang ditentukan.

d) Refleksi

Menurut Arikunto (2010:19), refleksi merupakan kegiatan untuk 
mengemukakakan kembali apa yang sudah dilakukan. Pada tahap refleksi yaitu mengkaji proses pembelajaran yang telah dilakukan. Proses pembelajaran tersebut dievaluasi dengan melihat ketercapaian dalam indikator kinerja pada siklus pertama, serta mengkaji kekurangan dan membuat daftar permasalahan yang muncul dalam pelaksanaan siklus pertama sehingga dapat dicari solusi yang lebih efektif agar terjadi peningkatan aktivitas belajar siswa. Hasil refleksi kemudian dibuat perencanaan untuk tindakan pada siklus berikutnya bersama tim kolaborasi. Data yang diperoleh pada lembar observasi dianalisis, kemudian dilakukan refleksi. Pelaksanaan refleksi berupa diskusi antara tim peneliti bersama tim kolaborasi yang bersangkutan. Diskusi tersebut bertujuan untuk mengevaluasi hasil tindakan yang dilakukan. Setelah itu mencari jalan keluar terhadap permasalahan- permasalahan yang timbul agar dapat dibuat rencana perbaikan pada siklus II.

Berdasarkan hasil observasi yang dilakukan pada proses pembelajaran di kelas III SD Dwijendra Denpasar diperoleh hasil bahwa metode pembelajaran yang digunakan guru adalah masih bersifat monoton, guru menggunakan metode ceramah, tidak ada media yang menarik perhatian siswa. Dalam menyampaikan materi guru masih menggunakan metode ceramah tanpa berbantuan teknik apapun. Kebiasaan guru yang ingin mendominasi kegiatan pembelajaran di kelas dapat mengakibatkan siswa memusatkan perhatian pada hal lain seperti bercanda bersama teman sebangkunya dan diikuti oleh siswa yang lain. Siswa cenderung tidak memahami apa yang sedang dipelajari, kurangnya konsentrasi siswa, timbulnya rasa malu dalam diri siswa untuk bertanya. Pembelajaran yang dilakukan di Sekolah Dasar Dwijendra Denpasar selama ini guru cenderung hanya menjalani kewajiban dan mengajar seadanya sehingga kelas menjadi hambar. Tidak ada upaya kreatif untuk mengubah kelas menjadi lebih hidup. Pembelajaran yang demikian mengakibatkan kebanyakan siswa tidak memiliki gairah dalam belajar, munculnya rasa bosan dan siswa mengantuk.

Tabel 3. Tabel Hasil Refleksi Pra Siklus

\begin{tabular}{|l|c|l|}
\hline \multicolumn{1}{|c|}{ Kriteria } & $\begin{array}{c}\text { Persentase Aktivitas Belajar } \\
\text { Siswa }\end{array}$ & \multicolumn{1}{c|}{ Keterangan } \\
\hline $\begin{array}{l}\text { Aktivitas belajar siswa } \\
\text { kelas III }\end{array}$ & $60,07 \%$ & $\begin{array}{l}\text { Hanya 6 orang cukup aktif, 16 } \\
\text { orang kurang aktif dan 2 orang } \\
\text { berada pada kategori sangat kurang } \\
\text { aktif. }\end{array}$ \\
\hline
\end{tabular}

Untuk mengetahui hasil pra siklus menggunakan rumus sebagai berikut:

\section{$\Sigma$}

Keterangan:

$\mathrm{M} \quad=$ Skor rata-rata aktivitas siswa

$\Sigma \quad=$ Jumlah skor aktivitas

= Banyaknya siswa

(dalam Agung, 2014)

Berdasarkan perhitungan di atas, maka rata-rata (mean) aktivitas belajar siswa adalah 18,21. Menentukan persentase rata-rata aktivitas belajar siswa digunakan rumus sebagai berikut:

Keterangan:

$\mathrm{P} \quad=$ Persentase rata-rata aktivitas belajar 
$\mathrm{M} \quad=$ Rata-rata skor

SMI = Skor Maksimal Ideal

Untuk mengtahui tingkat ketercapaian aktivitas belajar digunakan konversi PAP Skala lima tingkatan aktivitas belajar dapat menggunakan pedoman konversi PAP skala lima dilihat pada tabel

$$
=\frac{18,21}{30}=60,07 \%
$$

4.3 Kemudian dimodifikasi menjadi bentuk yang sederhana. Pedoman konversi PAP skala lima tentang kriteria penilaian aktivitas belajar siswa dapat dilihat pada tabel 4 
Tabel 4. Pedoman Konversi PAP Skala Lima tentang Aktivitas Belajar

\begin{tabular}{|l|l|l|}
\hline No & Persentase & Kriteria Aktivitas Belajar \\
\hline 1 & $90 \%-100 \%$ & Sangat Aktif \\
\hline 2 & $80 \%-89 \%$ & Aktif \\
\hline 3 & $65 \%-79 \%$ & Cukup Aktif \\
\hline 4 & $55 \%-64 \%$ & Kurang Aktif \\
\hline 5 & $0 \%-54 \%$ & Sangat Kurang Aktif \\
\hline
\end{tabular}

Berdasarkan Tabel tersebut, dapat diketahui bahwa aktivitas belajar siswa sebelum penelitian, diperoleh persentase aktivitas siswa sebesar $60,07 \%$ atau dari 24 siswa sebanyak 6 siswa yang cukup aktif di dalam kelas, sebanyak 16 siswa kurang aktif dan 2 siswa berada pada kategori sangat kurang aktif. Data ini selanjutnya menjadi bahan refleksi awal untuk memperbaiki proses pembelajaran melalui Penelitian Tindakan Kelas secara bersiklus yang terdiri dari perencanaan, observasi, pelaksanaan dan refleksi. Berikut deskripsi pelaksanaan tindakan Siklus I dan Siklus II.

\subsection{Hasil Penelitian Siklus I}

1) Data Aktivitas Belajar Siklus I

Data mengenai aktivitas belajar siswa di kelas III SD Dwijendra Denpasar pada siklus I dikumpulkan

Sebelum menghitung hasil yang diperoleh siswa, terlebih dahulu menghitung skor perolehan. Secara rinci hasil observasi pengamatan akhir siklus melalui observasi pengamatan berkalaborasi dengan guru, yang dilaksanakan pada pertemuan 1, pertemuan 2, dan pertemuan 3 untuk mengukur aktivitas belajar siswa. observasi yang digunakan berupa pengamatan di dalam kelas. Adapun hasil analisis data peningkatan aktivitas belajar pada siklus I, yaitu sebagai berikut.

a) Menentukan skor aktivitas belajar siswa

Pada siklus I, peneliti melakukan pemeriksaan terhadap observasi pengamatan berkolaborasi dengan guru kelas III untuk melihat peningkatan aktivitas belajar siswa. Skor hasil observasi pengamatan yang diperoleh siswa dianalisis menggunakan rumus:

pembelajaran tema 4 subtema 3 pembelajaran $\quad 1 \quad$ sampai pembelajaran 3 dapat dilihat pada lampiran

07.

b) Menghitung nilai rata-rata (mean) aktivitas belajar pada siklus I digunakan rumus berikut.

Keterangan:

$$
\mathrm{M}=\underline{\Sigma}
$$

$\mathrm{M}=$ Skor rata-rata aktivitas siswa

$\Sigma=$ Jumlah skor aktivitas

= Banyaknya siswa

(dalam Agung, 2014)

ketiga 515.

Diketahui jumlah skor pertemuan pertama 462, pertemuan kedua 497, dan pertemuan

$\begin{array}{rlrl}\text { Pertemuan Pertama } & : & \mathrm{M} & =\underline{\Sigma} \\ \mathrm{M} & = & =19,25 \\ \text { Pertemuan Kedua } & : & \mathrm{M} & =\underline{\Sigma}\end{array}$ 


$\begin{aligned} & \mathrm{M} \equiv \\ & =20,71 \\ \text { Pertemuan Ketiga } \quad: \quad \mathrm{M} & =\underline{\Sigma} \\ & \mathrm{M} \\ & =21,46\end{aligned}$


c) Menentukan persentase rata-rata aktivitas belajar siswa digunakan rumus sebagai berikut.

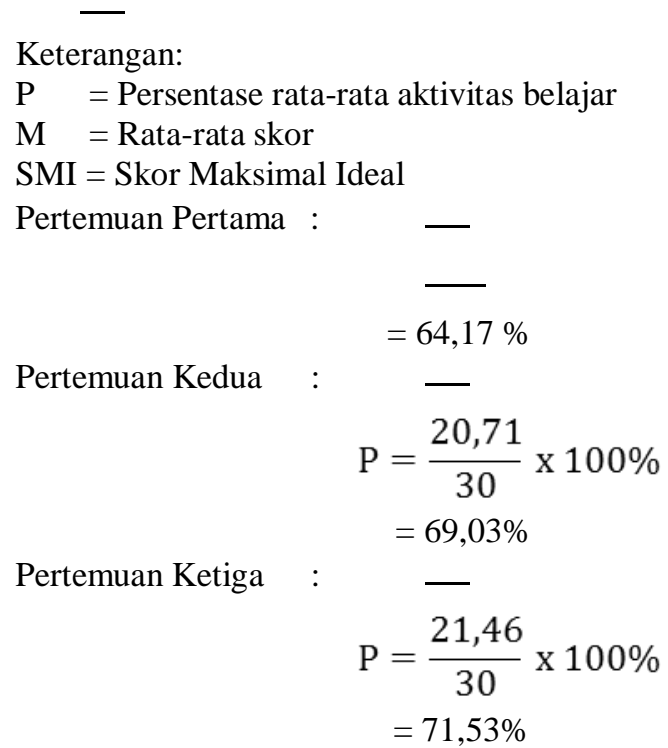

Menentukan persentase rata-rata aktivitas belajar siswa setiap siklus dengan rumus:

Persentase rata-rata aktivitas belajar siswa setiap siklus:

Berdasarkan hasil persentase rata-rata setiap pertemuan yang telah dicari, maka persentase aktivitas belajar siswa siklus I yaitu:

$\begin{aligned} \text { Persentase aktivitas belajar siswa siklus I } & \frac{64,17+69,03+71,53}{3} \\ & =\frac{204,73}{3} \\ & =68,24 \% \\ \text { Jadi aktivitas belajar siswa kelas } & \text { yang lebih maksimal dan indikator } \\ \text { mester II SD Dwijendra Denpasar } & \text { keberhasilan tercapai. }\end{aligned}$

III semester II SD Dwijendra Denpasar pada siklus I yaitu $68,24 \%$ dan dapat dikonversikan ke dalam tabel jika dikonversikan Penilaian Acuan Patokan (PAP) skala lima sebagai berikut:

Dari hasil perhitungan di atas dikemukakan bahwa persentase aktivitas belajar siswa kelas III semester II SD Dwijendra Denpasar pada siklus I adalah $68,24 \%$. Persentase aktivitas belajar siswa ini jika dikonversikan pada Penilaian Acuan Patokan (PAP) skala lima untuk kriteria aktivitas belajar siswa, maka aktivitas belajar untuk siklus I berada pada rentang 65\% - 79\% yaitu pada kriteria cukup aktif. Maka dari itu penelitian ini perlu dilanjutkan ke siklus berikutnya dengan melakukan beberapa penyempurnaan untuk memperoleh hasil
3.3 Hasil Tindakan pada Siklus II

1. Data Peningkatan Aktivitas Belajar Siklus II

Aktivitas belajar siswa selama pemberian tindakan pada siklus II diamati dalam setiap pembelajaran, sama seperti di awal yaitu dalam tiga kali pertemuan dan tiga kali observasi pengamatan berkalaborasi dengan guru. Secara umum aktivitas belajar siswa sudah mulai tampak terlihat meningkat. Hal ini menyebabkan banyak siswa yang berani untuk bertanya, menjawab dengan tepat, bekerjasama. Adapun hasil analisis data aktivitas belajar pada siklus II, yaitu sebagai berikut:

a) Menentukan skor aktivitas belajar 
siswa

Pada siklus II, peneliti melakukan pemeriksaan terhadap observasi pengamatan berkalaborasi dengan guru kelas III untuk melihat peningkatan aktivitas belajar siswa. Secara rinci hasil observasi pengamatan akhir siklus pembelajaran tema 4 subtema 3 pembelajaran 4 
sampai pembelajaran 6 dapat dilihat pada lampiran 11. Skor hasil observasi

Sebelum menghitung hasil yang diperoleh siswa, terlebih dahulu menghitung skor perolehan. Secara rinci hasil observasi pengamatan akhir siklus

b) Menghitung nilai rata-rata (mean) aktivitas belajar pada siklus II digunakan rumus berikut:

$$
\mathrm{M}=\underline{\Sigma}
$$

Keterangan:

M = Skor rata-rata aktivitas siswa

$\Sigma=$ Jumlah skor aktivitas

$$
\text { = Banyaknya siswa }
$$

(dalam Agung, 2014) ketiga 628.

Diketahui jumlah skor pertemuan pertama 547, pertemuan kedua 556, dan pertemuan

Pertemuan Pertama : $\mathrm{M}=\underline{\Sigma}$

$$
\begin{aligned}
M & =\frac{54 /}{24} \\
& =22,79 \\
\text { Pertemuan Kedua }: \quad M & =\frac{\Sigma}{5} \\
\text { Pertemuan Ketiga }: \quad M & =\frac{\Sigma}{24} \\
M & =\frac{0<8}{24} \\
M & =26,17 \\
& =26
\end{aligned}
$$

pengamatan yang diperoleh siswa dianalisis menggunakan rumus:

pembelajaran tema 4 subtema 2 pembelajaran $4 \quad$ sampai pembelajaran 6 dapat dilihat pada lampiran 08.

c) Menentukan persentase rata-rata aktivitas belajar siswa digunakan rumus sebagai berikut.

Keterangan:

$\mathrm{P} \quad=$ Persentase rata-rata aktivitas belajar

$\mathrm{M}$ = Rata-rata skor

SMI $=$ Skor Maksimal Ideal

Pertemuan Pertama :

$$
\begin{aligned}
P & =\frac{22,79}{30} \times 100 \% \\
& =75,97 \%
\end{aligned}
$$

Pertemuan Kedua

$$
\begin{aligned}
\mathrm{P}= & \frac{23,17}{30} \times 100 \% \\
& =77,23 \% \\
\text { Pertemuan Ketiga } \quad: \quad & - \\
\mathrm{P}= & \frac{26,17}{30} \times 100 \%
\end{aligned}
$$


$=87,23 \%$ 
d) Persentase rata-rata aktivitas belajar siswa setiap siklus

Menentukan persentase rata-rata aktivitas belajar siswa setiap siklus dengan rumus: Persentase rata-rata aktivitas belajar siswa setiap siklus:

Berdasarkan hasil persentase rata-rata setiap pertemuan yang telah dicari, maka persentase aktivitas belajar siswa siklus II yaitu:

Persentase aktivitas belajar siswa siklus II $=\frac{75,97+77,23+87,23}{3} \times 100 \%$

$$
=\overline{ }=\overline{80,14 \%}
$$

Dari hasil perhitungan di atas dikemukakan bahwa persentase aktivitas belajar siswa kelas III semester II SD Dwijendra Denpasar pada siklus II adalah 80,14\%. Persentase aktivitas belajar siswa ini jika dikonversikan pada Penilaian Acuan Patokan (PAP) skala lima untuk kriteria aktivitas belajar siswa, maka

aktivitas belajar untuk siklus II berada pada rentang $80 \%$ - $89 \%$ yaitu pada kriteria "aktif".

Adapun rekapitulasi data aktivitas belajar siswa kelas III SD Dwijendra Denpasar pra siklus, siklus I dan siklus II dapat dilihat pada tabel berikut.

Tabel 5. Tabel Rekapitulasi Data aktivitas Belajar Siswa Kelas III SD Dwijendra Denpasar

\begin{tabular}{|c|c|c|c|}
\hline Data & Pra Siklus & Siklus I & Siklus II \\
\hline $\begin{array}{c}\text { Persentase rata-rata aktivitas } \\
\text { belajar siswa }\end{array}$ & $60,07 \%$ & $68,24 \%$ & $80,14 \%$ \\
\hline
\end{tabular}

Berdasarkan rekapitulasi data tersebut, dapat disajikan pada grafik histogram sebagai berikut:

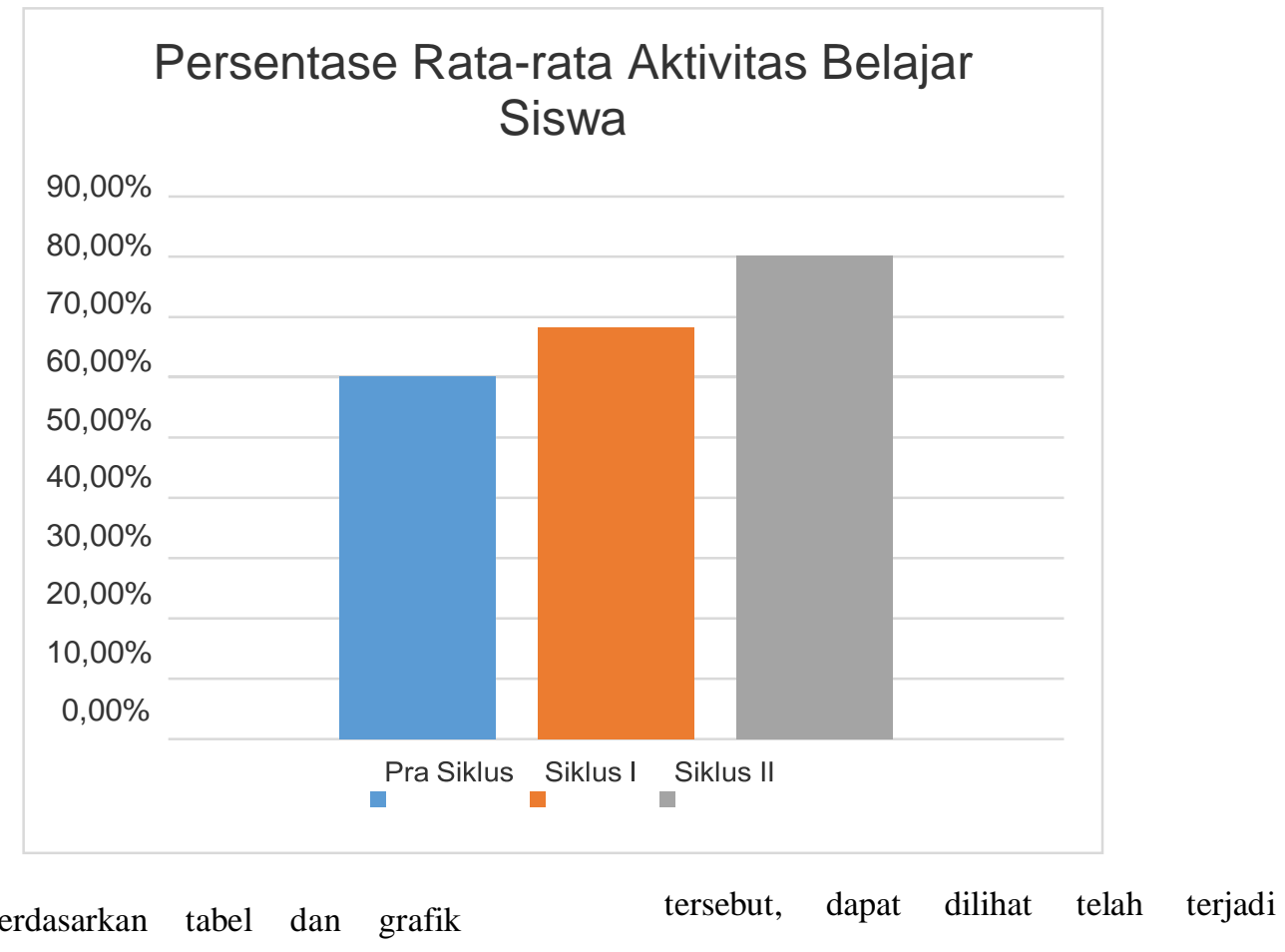


peningkatan pada persentase aktivitas belajar siswa. Dari data yang diperoleh pada siklus II, indikator yang diharapkan dalam penelitian ini sudah terpenuhi. Hal ini dapat dilihat pada data yang diperoleh, yakni aktivitas belajar siswa sudah mencapai persentase rata-rata yang diharapkan yakni $80,14 \%$. Jika dikonversikan pada 
tabel PAP skala lima maka ketuntasan berada pada persentase antara $80-89 \%$ dengan kriteria aktif. Oleh karena itu, penelitian ini dapat dikatakan berhasil atau penelitian dapat dihentikan karena sudah mencapai indikator keberhasilan yang diharapkan.

Aktivitas belajar siswa kelas III SD Dwijendra Denpasar pada refleksi awal atau sebelum tindakan masih rendah. Hal ini ditunjukan oleh sebelum pelaksanaan tindakan pra siklus dalam observasi dan wawancara guru, diketahui bahwa SD Dwijendra Denpasar siswa masih kurang aktif yaitu siswa belum mencapai kriteria aktif minimal (80\%).

Rendahnya aktivitas belajar siswa kelas III SD Dwijendra Denpasar proses pembelajaran masih didominasi oleh guru, sehingga siswa terlihat pasif dalam proses pembelajaran sesuai pengamatan yang dilakukan, kurangnya aktivitas siswa dalam proses pembelajaran menjadikan perhatian dan motivasi siswa kurang terhadap materi yang dipelajari, sehingga tingkat pemahaman siswa terhadap materi yang dipelajari juga rendah. Rendahnya tingkat pemahaman siswa terhadap materi yang dipelajari berdampak terhadap hasil belajar yang diperoleh siswa.

Berdasarkan permasalahan yang dikemukakan pada waktu refleksi awal, peneliti berkolaborasi dengan guru untuk penerapan model pembelajaran kooperatif tipe cooperative integrated reading and composition diselipkan teknik ice breaking pada tema 4 sub tema 3 pembelajaran 1 sampai pembelajaran 3 untuk memperbaiki proses pembelajaran pada siklus I.

Pada siklus I persentase rata-rata aktivitas belajar siswa kelas III SD Dwijendra Denpasar siswa mengalami peningkatan. Adapun persentase rata-rata $68,24 \%$ hasil tersebut belum dapat memenuhi indikator keberhasilan yang ditetapkan. Hal ini pada siklus I juga masih banyak ditemukan hambatan atau kekurangan dalam proses pembelajaran. Kekurangan-kekurangan tersebut antara lain:

1) siswa cenderung bermain pada saat guru menjelaskan materi dan diikuti oleh siswa yang lain, hal ini dikarenakan siswa terfokus terhadap hal-hal diluar pembelajaran, 2) siswa merasa bosan dikarenakan tidak ada jeda pada saat proses pembelajaran berlangsung, 3) siswa malu untuk bertanya dikarenakan siswa tidak memahami pembelajaran, 4) siswa kurang antusias mengikuti proses pembelajaran, hal ini disebabkan oleh kebiasaan guru yang tidak menggunakan teknik pembelajaran saat mengajar, 5) model pembelajaran terlihat pasif karena belum melibatkan siswa secara berkelompok, 6) pembelajaran cenderung kaku karena masih didominasi oleh guru.

Untuk mengatasi kendala-kendala yang dihadapi dalam kegiatan pembelajaran pada siklus I, peneliti berkolaborasi bersama dengan guru mendiskusikan perbaikan tindakan untuk selanjutnya diterapkan pada siklus II. Perbaikan tindakan yang dilakukan, diantaranya sebagai berikut: 1) melakukan pendekatan terhadap siswa yang menekankan pada keterkaitan antara materi pembelajaran dengan dunia kehidupan siswa secara nyata, sehingga para siswa mampu menghubungkan dan menerapkan kompetensi aktivitas belajar dalam kehidupan sehari-hari, 2) mencari data tentang masalah, yaitu dengan berkomunikasi dengan orang tua siswa dan wali kelas dengan menyampaikan teguran atau kritik secara spesifik, seperti kapan waktu terjadi tindakannya, perilakunya seperti apa, serta apa akibatnya. Misalnya, "Ibu, saya ingin memberi tahu bahwa beberapa hari yang lalu saat jam istirahat, anak ibu berkelahi dan mengakibatkan seorang temannya terluka." Informasi yang disampaikan haruslah bersifat faktual, jelas waktu dan tindakan yang dilakukan serta akibat yang ditimbulkan. Cara penyampaian masalah seperti ini akan lebih membangun serta lebih mudah diterima oleh orang tua, 3) melakukan konsultasi secara pribadi, hal ini dikarenakan anak usia sekolah dasar memerlukan perhatian khusus agar siswa dapat mencapai prestasi belajar dan segenap potensi yang dimiliki siswa dapat berkembang secara optimal tanpa mengalami hambatan dan permasalahan yang cukup berarti, 4) memberikan penjelasan langkah-langkah pembelajaran yang akan dilaksanakan dengan jelas dan memberikan jeda waktu siswa untuk mengemukakan pertanyaan jika ada yang kurang dalam pembelajaran tema untuk memastikan seluruh siswa memahami setiap langkah pembelajaran 
yang akan dilakukan, 5) sebelum siswa melakukan penerapan model pembelajaran kooperatif tipe cooperative integrated reading and composition peneliti menjelaskan bahwa siswa diberikan penjelasan terlebih dahulu kemudian membuat kelompok, 1 kelompok minimal 2-3 orang, kemudian guru memberikan pembisaan membaca 15 menit diselipkan teknik ice breaking, 6) Mengarahkan siswa dalam membuat simpulan dengan memberikan pertanyaan pancingan yang mengarah pada simpulan yang diharapkan. Setiap siswa diberikan kesempatan untuk menanggapi simpulan temannya, 7) Mengingatkan alokasi waktu yang masih tersisa 15 menit sebelum waktu habis untuk melakukan kegiatan sehingga waktu yang diperlukan menjadi tepat dengan waktu yang disediakan.

Melalui refleksi pada siklus I, peneliti menyiapkan kembali skenario dalam RPP, setelah melakukan perbaikan proses pembelajaran pada siklus II aktivitas belajar siswa mengalami peningkatan. Hal ini ditunjukan dengan persentase rata-rata sebesar 80,14\%. Data tersebut dapat membuktikan Penerapan model pembelajaran kooperatif tipe Cooperative Integrated Reading and Composition Diselipkan Teknik Ice Breaking memang tepat digunakan untuk meningkatkan aktivitas belajar di sekolah dasar, khususnya pada siswa Kelas III SD Dwijendra Denpasar.

Aktivitas belajar siswa mengalami peningkatan karena siswa merasa tertarik menerapkan model pembelajaran kooperatif tipe Cooperative Integrated Reading and Composition menurut menurut Sriyono (dalam Chaniago: 2010: 1) menyatakan bahwa aktivitas adalah segala kegiatan yang dilaksanakan baik secara jasmani atau rohani. Aktivitas siswa selama proses belajar mengajar merupakan salah satu indikator adanya keinginan siswa untuk belajar. Aktivitas belajar siswa ditentukan oleh aktivitas yang dilakukan siswa selama proses pembelajaran. Aktivitas belajar merupakan segala sesuatu yang dilakukan saat proses pembelajaran berlangsung. Berdasarkan pendapat diatas, peneliti menyimpulkan bahwa model pembelajaran kooperatif tipe CIRC adalah model pembelajaran yang memfokuskan siswa pada pengajaran membaca dan menulis, khususnya dalam pelajaran tema 4 sub tema
3. Adapun langkah-langkah penerapan model pembelajaran kooperatif tipe CIRC yaitu merupakan suatu model pembelajaran dimana siswa dibagi menjadi beberapa kelompok untuk melakukan diskusi, selanjutnya guru mengarahkan tiap-tiap kelompok untuk menerapkan bacaan. Tipe ini melibatkan banyak siswa dalam menelaah materi yang tercakup dalam suatu pelajaran dan memberikan kesempatan kepada siswa untuk saling membagi ide-ide dan mencapai tujuan pembelajaran yang diharapkan sehingga peneliti menggunakan pendapat dari Shohimin (2014:53) dan (Kurniasih \& Sani, 2016 : 90).

Berdasarkan pemaparan tersebut, dapat disimpulkan bahwa Model pembelajaran kooperatif tipe Cooperative Integrated Reading and Composition diselipkan teknik ice breaking adalah model pembelajaran yang memunculkan suasana yang lebih menyenangkan dan efisien sehingga mampu membangkitkan kreativitas dan meningkatkan kemampuan berfikir siswa, serta memaksimalkan ketajaman konsentrasi siswa melalui pembelajaran dengan melibatkan siswa dalam kelompok.

Nilai rata-rata siswa mengalami peningkatan karena bahwa model pembelajaran kooperatif Cooperative Integrated Reading and Composition merupakan suatu model pembelajaran dengan menggunakan teknik ice breaking yang menyenangkan dan membuat siswa terfokus terhadap proses pembelajaran. Adanya peningkatan tersebut menunjukkan bahwa aktivitas belajar siswa bertambah sehingga aktivitas belajar siswa mengalami peningkatan. Peningkatan tersebut sudah mencapai indikator keberhasilan yang ditentukan. Nilai siswa secara individu mengalami peningkatan yang cukup baik. Hal ini menjadikan skor persentase rata-rata $80,14 \%$ meningkat. Dengan adanya peningkatan tersebut, maka terbukti bahwa Penerapan model pembelajaran kooperatif tipe Cooperative Integrated Reading and Composition mampu meningkatkan akivitas belajar siswa.

Hasil penelitian ini mendukung hasil penelitian yang dilakukan oleh Khusnul Khotimah (2010) yang berjudul "Penerapan model pembelajaran kooperatif tipe CIRC untuk meningakatkan aktivitas dan hasil belajar siswa kelas IV SDN Tegal Gede 02 Jember Tahun Ajaran 2010/2011”. 
Peningkatan aktivitas belajar tersebut dilihat dari adanya peningkatan nilai ratarata siswa, jumlah siswa yang memperoleh nilai aktif. Selain itu, hasil penelitian ini juga mendukung hasil penelitian yang dilakukan oleh Penelitian dari Aulia Rahmawati dan Ariyanti Eka Silviani yang berjudul "Pengaruh Model Pembelajaran Cooperative Integrated Reading and Composition Terhadap Aktivitas dan Hasil Belajar IPS Kelas IV di SDN Gugus Mawardi Kendal Tahun Pelajaran 2017/2018". Adanya peningkatan nilai ratarata dan jumlah siswa yang memperoleh nilai pada kategori aktif membuktikan model pembelajaran kooperatif tipe Cooperative Integrated Reading and Composition Diselipkan Teknik Ice Breaking dapat meningkatkan aktivitas belajar siswa kelas III di SD Dwijendra Denpasar.

\section{PENUTUP}

\subsection{Simpulan}

Penerapan model pembelajaran kooperatif tipe cooperative integrated reading and composition diselipkan teknik ice breaking dapat meningkatkan aktivitas belajar siswa kelas III SD Dwijendra Denpasar. Hal ini dapat dilihat dari persentase rata-rata aktivitas belajar yang diperoleh yaitu pada refleksi awal rata-rata aktivitas belajar hanya mencapai berdasarkan hasil penelitian dari siklus I sampai pada siklus ke II. Aktivitas belajar berupa persentase rata-rata pada siklus I $68,24 \%$ yang berada pada kategori cukup aktif. Setelah diadakan perbaikan tindakan pada siklus II, rata-rata aktivitas belajar siswa semakin meningkat menjadi $80,14 \%$ berada pada ketegori aktif sehingga 
terjadinya peningkatan persentase rat-rata aktivitas belajar siswa dari siklus I ke siklus II sebesar $11,09 \%$.

\subsection{Saran}

Berdasarkan penelitian yang telah dilakukan, peneliti mempunyai beberapa saran sebagai berikut: (1) Bagi siswa disarankan agar belajar dengan baik, kurangi bermain agar mudah memahami materi yang sedang dibahas, (2) Bagi guru diharapkan menerapkan Penerapan model pembelajaran kooperatif tipe Cooperative Integrated Reading and Composition Diselipkan Teknik Ice Breaking dalam pembelajaran sebagai alternatif dalam meningkatkan aktivitas belajar siswa. (3) Penerapan model pembelajaran kooperatif tipe Cooperative Integrated Reading and Composition diselipkan teknik ice breaking dapat mendorong siswa lebih aktif dan dapat meningkatkan aktivitas belajar siswa. (4) Kepada peneliti lain disarankan melakukan penelitian yang sejenis untuk mengetahui efektifitas Penerapan model pembelajaran kooperatif tipe Cooperative Integrated Reading and Composition Diselipkan Teknik Ice Breaking pada sekolah yang berbeda.

\section{DAFTAR PUSTAKA}

Abdul Majid. 2014. Pembelajaran Tematik Terpadu. Bandung: Remaja Rosdakarya. Arikunto, Suharsimi. 2010. Prosedur Penelitian. Jakarta: Rineka Cipta.

Arikunto, Suharsimi. 2014. Prosedur Penelitian Suatu Pendekatan Praktik. Jakarta : Rineka Cipta.

Pusat Kurikulum Kemendikbud. Uji publik Kurikulum 2013. Diakses 04 September $\quad 2020 \quad$ dari http://www.kemendiknas.go.id.
Santika, I. G. N. (2018). Strategi Meningkatkan Kualitas SDM Masyarakat Desa Padangsambian Kaja Melalui Pendidikan Karakter Berbasiskan Kepedulian Lingkungan Untuk Membebaskannya Dari Bencana Banjir. Widya Accarya. 9 (2).

Santika, I Gusti Ngurah. 2017. Kepala Sekolah Dalam Konsep Kepemimpinan Pendidikan: Suatu Kajian Teoritis. Widya Accarya. 7 (1)

Santika, I. G. N., Rindawan, I. K., \& Sujana, I. G. (2019). Memperkuat Pancasila Melalui Pergub No. 79 Tahun 2018 Dalam Menanggulangi Pengikisan Budaya Di Era Revolusi Industri 4.0. Prosiding Seminar Nasional Inobali 2019, 79, 981-990

Sila.2013. Perubahan Paradigma Guru dalam Menyongsong Pembinaan dan Pengembangan Profesi Guru, Majalah Widya Acarya edisi 2 : FKIP Universitas Dwijendra. Vol. 3 No. $1 /$ 2014.

Slavin, R. E. 2010. Cooperative Learning Teori, Riset dan Praktik. Bandung: Nusa Media. Sunarto. 2012. Ice breaker dalam Pembelajaran Aktif. Surakarta: Cakrawala Media.

Swarniti, N. W. (2021). A Corpus Based Approach to the Analysis of Structures in Prepositional Phrase. Yavana Bhasha: Journal of English Language Education, 4(1), 18-22.

$\begin{array}{lrr}\text { Trianto. } 2011 . & \text { Mendesain } & \text { Model } \\ \text { Pembelajaran } & \text { Inovatif-Progresif: } \\ \text { Konsep, } & \text { Landasan, } & \text { dan } \\ \text { Implementasinya pada } & \text { Kurikulum } \\ \text { Tingkat Satuan } & \text { Pendidikan } & \text { (KTSP). } \\ \text { Jakarta: Kencana. } & & \end{array}$

